\title{
Pengaruh Pendidikan Kesehatan dan Pemberian Daun Seledri pada Pasien Dengan Hipertensi di Wilayah RT 10 Kelurahan Murni
}

\author{
Amelia Ade Anggraini ${ }^{1}$, Vevi Suryenti Putri ${ }^{2}$, Zuli Nuranti ${ }^{3}$ \\ ${ }^{1,3}$ Prodi Profesi Ners, Sekolah Tinggi Ilmu Kesehatan Baitiurrahim Jambi \\ ${ }^{2}$ Prodi SI Keperawatan, Sekolah Tinggi Ilmu Kesehatan Baitiurrahim Jambi \\ Email:vevisuryentiputri.2010@gmail.com
}

Submitted : 10/10/2019

Accepted: $17 / 10 / 2019$

Published: 30/11/2019

\begin{abstract}
Hypertension is a non-communicable disease which is an important health problem throughout the world because its prevalence is quite high and continues to increase and its relationship with cardiovascular disease, stroke, retinopathy, and kidney failure. Based on the assessment conducted through interviews, observations, and distribution of questionnaires obtained data in RT 10 Kelurahan Murni with a total of 47 families and 172 inhabitants of the population of 39 elderly obtained hypertension percentage of $38.7 \%$ and $50 \%$ of the community if sick only take medication from shop. Counseling activities carried out for 45 minutes with the stages of directing participants to the place to be counseling, opening which was delivered by the moderator, delivering counseling material delivered by the presenter, demonstrating how to make a decoction of celery leaves, evaluating the extension participants, distributing leaflets to participants and documenting activities. The results of counseling $80,56 \%$ of participants were able to explain the understanding of hypertension, mention the causes of hypertension, 77,78\% mention the signs and symptoms of hypertension, 77,7\% explain the prevention of hypertension, $83,33 \%$ mention foods that are allowed, 86,11\% mention foods that are not allowed, 86,11\% can make herbal ingredients using celery leaves.
\end{abstract}

Keywords : blood pressure, celery, hypertension.

\begin{abstract}
Abstrak
Hipertensi merupakan salah satu penyakit yang tidak menular yang menjadi masalah kesehatan penting di seluruh dunia karena prevalensinya yang cukup tinggi dan terus meningkat serta hubungannya dengan penyakit kardiovaskuler, stroke, retinopati, dan gagal ginjal. Berdasarkan pengkajian yang dilakukan melalui wawancara, observasi, dan penyebaran kuesioner didapatkan data di RT 10 Kelurahan Murni dengan jumlah 47 KK dan 172 jiwa penduduk yaitu dari jumlah 39 lansia didapatkan adalah hipertensi persentase 38,7 \% dan 50\% masyarakat jika sakit hanya meminum obat dari warung. Kegiatan penyuluhan dilaksanakan selama 45 menit dengan tahapan mengarahkan peserta ke tempat yang akan dilakukan penyuluhan, melakukan pembukaan yang disampaikan oleh moderator, menyampaikan materi penyuluhan yang disampaikan oleh penyaji, mendemonstrasikan cara membuat rebusan daun seledri, melakukan evaluasi pada peserta penyuluhan, membagikan leaflet pada peserta dan mendokumentasikan kegiatan. Hasil dari penyuluhan $80,56 \%$ peserta mampu menjelaskan kembali pengertian hipertensi, $77,78 \%$ menyebutkan penyebab hipertensi, $75 \%$ menyebutkan tanda dan gejala hipertensi, $77,7 \%$ menjelaskan pencegahan hipertensi, 83,33\% menyebutkan makanan yang diperbolehkan, $77,78 \%$ menyebutkan makanan yang tidak diperbolehkan, $86,11 \%$ dapat membuat ramuan herbal dengan menggunakan daun seledri.
\end{abstract}

Kata Kunci : hipertensi, seledri, tekanan darah 


\section{PENDAHULUAN}

Hipertensi merupakan salah satu penyakit yang tidak menular yang menjadi masalah kesehatan penting di seluruh dunia karena prevalensinya yang cukup tinggi dan terus meningkat serta hubungannya dengan penyakit kardiovaskuler, stroke, retinopati, dan gagal ginjal. Hipertensi juga menjadi faktor risiko terbesar yang menyebabkan kematian. Hipertensi adalah suatu peningkatan abnormal tekanan darah dalam pembuluh darah arteri secara terus-menerus lebih dari suatu periode. Hal ini terjadi bila arteriole-arteriole konstriksi. Konstriksi arteriole membuat darah sulit mengalir dan meningkatkan tekanan melawan dinding arteri. Hipertensi menambah beban kerja jantung dan arteri yang bila berlanjut dapat menimbulkan kerusakan jantung dan pembuluh darah (Udjianti, 2010).

Riskesdas (2018) melaporkan bahwa di Indonesia prevalensi hipertensi berdasarkan hasil pengukuran pada penduduk umur $\geq 18$ tahun mengalami peningkatan yaitu $25,8 \%$ di tahun 2013 menjadi 34,1\% pada tahun 2018. Sedangkan di Provinsi Jambi angka hipertensi mencapai 30,2\% di tahun 2013 dan meningkat hingga $32,8 \%$ di tahun 2018. Banyaknya penderita hipertensi diperkirakan sebesar 15 juta bangsa Indonesia tetapi hanya $4 \%$ yang mampu mengendalikan hipertensi (controlled hypertension). Yang dimaksud dengan hipertensi terkendali adalah mereka menderita hipertensi dan sedang berobat sehingga terkendali dari kemungkinan serangan kenaikan tekanan darah yang berlebihan (Bustan, 2015).

Penatalaksanaan hipertensi dapat dilakukan dengan 2 cara yaitu secara farmakologis dan non farmakologis. Penatalaksanaan dapat menurunkan resiko penyakit kardiovaskular dan mortalitas serta morbiditas yang berkaitan. Kondisi patologis hipertensi memerlukan penanganan atau terapi. Tujuan penanganan atau terapi adalah mencapai dan mempertahankan tekanan sistolik dibawah
$140 \mathrm{mmHg}$ dan tekanan diastolik $90 \mathrm{mmHg}$ dan mengontrol faktor resiko. Hal ini dapat dicapai melalui modifikasi gaya hidup saja (non farmakolgis), atau dengan pengobatan hipertensi (farmakologis) (Aspiani, 2015). Pencegahan lain hipertensi adalah dengan pemberian rebusan daun seledri (Muzakar, 2012).

Daun seledri banyak mengandung apiin, suatu senyawa yang bersifat diuretik dan diduga mampu melebarkan pembuluh darah. Seledri telah banyak digunakan di masyarakat dan telah banyak dilakukan penelitian mengenai efek farmakologinya dan telah terbukti mampu menurunkan tekanan darah tinggi (Muzakar, 2012). Kandungan Apigenin, dalam seledri berfungsi sebagai beta blocker yang dapat memperlambat detak jantung dan menurunkan kekuatan kontraksi jantung sehingga aliran darah yang terpompa lebih sedikit dan tekanan darah menjadi berkurang. Manitol dan apiin, bersifat diuretic yaitu membantu ginjal mengeluarkan kelebihan cairan dan garam dari dalam tubuh, sehingga berkurangnya cairan dalam darah akan menurunkan tekanan darah (Asmadi, 2012). Selain itu selederi juga mengandung pthalides dan magnesium yang baik untuk membantu melemaskan otot sekitar pembuluh darah arteri dan membantu menormalkan penyempitan pembuluh darah serta dapat mereduksi hormone stress yang dapat meningkatkan tekanan darah dikutip dari Afifah (2009).

Menurut penelitian Intan Eka Oktavia, Junaidi dan Ainurafiq ( 2017 ) tentang Pengaruh Pemberian Air Rebusan Daun Seledri (Apium Graveolens) Terhadap Penurunan Tekanan Darah Sistolik Dan Diastolik Penderita Hipertensi Di Wilayah Kerja Puskesmas Puuwatu Kota Kendari Tahun 2016" . Hasil uji statistik untuk mengetahui perbedaan tekanan darah sistolik dan diastolik penderita hipertensi kelompok perlakuan dan kelompok kontrol pada hari pertama dan hari kedua setelah pemberian Air 
rebusan seledri sebelum dan sesudah mengendalikan kovariat didapatkan nilai signifikansi $\mathrm{p}<0,05$ sehingga disimpulkan bahwa ada perbedaan yang bermakna tekanan darah sistolik dan diastolik pada kelompok perlakuan dan kelompok Kontrol, sebelum maupun sesudah mengendalikan Kovariat.

Hal ini juga didukung dengan penelitian yang dilakukan oleh Sri Sakinah dan Husnul Khatimah Azhari yang berjudul "Pengaruh Rebusan Daun Seledri Terhadap Penurunan Tekanan Darah Pada Pasien Hipertensi Di Wilayah Kerja Puskesmas Pangkajene Kabupaten Sidrap “ (2018) dengan Hasil penelitian menunjukkan adanya Pengaruh Pemberian Rebusan Daun Seledri Terhadap Penuruanan Tekanan Darah Pada Penderita Hipertensi nilai $(p=0,000)$. Berdasarkan hasil penelitian tersebut dapat disimpulkan bahwa ada pengaruh antara rebusan daun seledri terhadap penurunan tekanan darah pada pasien hipertensi. Hipertensi dianggap sebagai penyakit serius karena dampak yang ditimbulkan sangat luas, bahkan dapat menyebabkan kematian. Kematian terjadi akibat dampak hipertensi itu sendiri atau penyakit lain yang diawali oleh hipertensi, seperti kerusakan ginjal, serangan jantung, dan stroke (Lingga,2012). Menurut Menteri Kesehatan Prof. Tjandra upaya pencegahan dan penanggulangan hipertensi dimulai dengan meningkatkan kesadaraan masyarakat dan perubahan pola hidup kearah yang lebih sehat (Depkes, 2012). Untuk pengendalian hipertensi diperlukan pengetahuan dan kesadaran akan keberadaan dan risiko hipertensi. Masalahnya, hipertensi disebut juga "silent killer" karena tidak mempunyai atau disadari akan keberadaannya. Karena itu, diperlukan pemeriksaan tekanan darah secara teratur (Udjianti, 2015).

Dari penelitian Nur Haryani, Subiyanto, dan Nunuk Suryani (2018) tentang "Pengaruh Penyuluhan Hipertensi Terhadap Perubahan Perilaku Berisiko Pada Pasien Hipertensi " menunjukkan bahwa ada pengaruh penyuluhan kesehatan terhadap pengetahuan perilaku klien hipertensi, dimana ada pengaruh pendidikan kesehtan hipertensi terhadap pengetahuan hipertensi $(\mathrm{p}<0,001)$. Ada pengaruh pendidikan kesehatan hipertensi terhadap sikap penderita hipertensi $(\mathrm{p}=0,014)$.

Berdasarkan hasil pendataan yang dilakukan kelompok pada tanggal pada tanggal 06 November 2019 didapatkan beberapa masalah yang dilakukan melalui wawancara, observasi dan penyebaran kuesioner di RT 10 Kelurahan Murni yaitu kader mengatakan penyakit yang banyak dialami oleh lansia RT 10 dari jumlah 39 lansia didapatkan adalah hipertensi persentase 38,7 \% dan 50\% masyarakat jika sakit hanya meminum obat dari warung. Dari hasil wawancara masyarakat banyak yang jarang memeriksakan kesehatan secara teratur, banyak yang lebih memilih pengobatan secara herbal karena takut mengkonsumsi obat-obatan medis, masyarakat banyak yang tidak menyadari pentingnya menerapkan pola hidup sehat padahal sudah menderita hipertensi karena tidak mengetahui bagaimana pola hidup yang sehat bagi penderita hipertensi.

Berdasarkan permasalahan yang telah didapatkan, untuk meningkatkan kesadaran masyarakat tentang akibat lanjut dari hipertensi sehingga masyarakat mau melaksanakan pencegahan hipertensi maka perlu diadakan penyuluhan kesehatan tentang pencegahan dan akibat lanjut dari hipertensi untuk merubah perilaku masyarakat ke gaya hidup yang lebih sehat.

\section{TARGET DAN LUARAN}

Adapun target luaran dalam penyuluhan ini adalah diharapkan di RT 10 Kelurahan Murni yaitu masyarakat mampu menjelaskan kembali pengertian hipertensi, menyebutkan penyebab hipertensi, menyebutkan tanda dan gejala hipertensi, menyebutkan faktor resiko yang mempengaruhi hipertensi, menjelaskan komplikasi hipertensi, menjelaskan 
pencegahan hipertensi, menyebutkan makanan yang diperbolehkan, menyebutkan makanan yang tidak diperbolehkan, serta dapat membuat ramuan herbal dengan menggunakan daun seledri.

Rencana tindak lanjut dari kegiatan penyuluhan tentang hipertensi adalah Berkoordinasi dengan pihak puskesmas program prnyakit tidak menular (PTM) untuk melakukan penyuluhan tentang hipertensi dengan melibatkan posbindu yang diselenggarakan 1 bulan sekali di 5 kelurahan.

\section{METODE PELAKSANAAN}

Pelaksanaan kegiatan selama 45 menit dengan tahapan mengarahkan peserta ke tempat yang akan dilakukan penyuluhan, melakukan pembukaan yang disampaikan oleh moderator, menyampaikan materi penyuluhan yang disampaikan oleh penyaji, mendemonstrasikan membuat rebusan daun seledri, melakukan evaluasi pada peserta penyuluhan, membagikan leaflet pada peserta dan mendokumentasikan kegiatan. Hasil dari penyuluhan peserta menjelaskan kembali pengertian hipertensi, menyebutkan penyebab hipertensi, menyebutkan tanda dan gejala hipertensi menyebutkan faktor resiko yang mempengaruhi hipertensi, menjelaskan komplikasi hipertensi, menjelaskan pencegahan hipertensi, menyebutkan makanan yang diperbolehkan, menyebutkan makanan yang tidak diperbolehkan, serta dapat membuat ramuan herbal dengan menggunakan daun seledri.

\section{HASIL DAN PEMBAHASAN A. Hasil}

Sebelum disampaikan penyuluhan, kelompok melakukan pre test untuk menggali pengetahuan lansia dan keluarga yang didapatkan hasil pengetahuan baik $63,89 \%$ tentang pengertian hipertensi. Setelah dilakukan penyuluhan didapatkan hasil post test dengan pengetahuan baik
80,56\%. Dari hasil tersebut dapat ditarik kesimpulan bahwa lansia dan keluarga yang telah diberi penyuluhan bisa mengerti dan memahami pengertian dari hipertensi sebagai berikut : Hipertensi adalah suatu keadaan ketika seseorang mengalami peningkatan tekanan darah di atas normal yang mengakibatkan peningkatan angkan kesakitan (morbiditas) dan angka kematian (mortalitas) (Kushariyadi, 2008 dalam Aspiani, 2015). Pre test yang kedua yang dilakukan kelompok mengenai penyebab hipertensi didapatkan hasil pengetahuan baik $63,89 \%$ dan setelah dilakukan penyuluhan didapatkan hasil post test dengan pengetahuan baik $77,78 \%$. Hal ini menunjukkan terjadi peningkatan pemahaman lansia dan keluarga dalam memahami penyebab hipertensi sebagai berikut: Genetik, Obesitas, Stress karena lingkungan, hilangnya elastisitas jaringan arterosklerosis (Aspiani,2015) Pre test yang ketiga yang dilakukan oleh kelompok mengenai tanda dan gejala hipertensi didapatkan hasil pengerahuan baik 58,33\% dan setelah dilakukan penyuluhan didapatkan hasil post test dengan pengetahuan baik $75 \%$. Hasil penyuluhan bahwa lansia dan keluarga dapat menyebutkan tanda dan gejala dari hipertensi sebagai berikut: Gejala ringan seperti pusing atau sakit kepala, sering gelisah, wajah merah, tengkuk terasa pegal, mudah marah, telinga berdengung, sukar tidur, sesak napas, rasa berat ditengkuk, mudah lelah, mata berkunang-kunang, mimisan ( keluar darah dari hidung). Pre test yang keempat yang dilakukan oleh kelompok mengenai pencegahan hipertensi didapatkan pengetahuan baik $61,11 \%$ dan setelah dilakukan penyuluhan didapatkan hasil post test dengan pengetahuan baik $77,78 \%$. Hasil penyuluhan bahwa lansia dan keluarga dapat pencegahan dari hipertensi sebagai berikut:

1. Mengurangi konsumsi garam

2. Menghindari kegemukan (obesitas)

3. Membatasi konsumsi lemak

4. Olahraga teratur

5. Makan banyak buah dan sayur segar 
6. Latihan relaksasi atau meditasi

7. Berusaha membina hidup yang postif

Pre test yang kelima yang dilakukan oleh kelompok mengenai makanan yang dibolehkan untuk dikonsumsi bagi penderita hipertensi didapatkan hasil pengetahuan baik $61,11 \%$ dan setelah dilakukan penyuluhan didapatkan hasil post test dengan pengetahuan baik 83,33\%. Hasil penyuluhan bahwa lansia dan keluarga dapat menyebutkan makanan yang diperbolehkan bagi hipertensi sebagai berikut:

1) Bayam

2) Kacang-kacangan

3) Pisang

4) Kedelai

5) Kentang

6) Coklat pekat

Pre test yang keenam yang dilakukan oleh kelompok mengenai makanan yang tidak dianjurkan untuk dikonsumsi bagi hipertensi didapatkan hasil pengetahuan baik $61,11 \%$ dan setelah dilakukan penyuluhan didapatkan hasil post test dengan pengetahuan baik $77,78 \%$. Hasil penyuluhan bahwa lansia dan keluarga dapat menyebutkan makanan yang tidak dianjurkan bagi hipertensi sebagai berikut:

1) Roti, kue yang dimasak dengan garam dapur atau soda.

2) Ginjal, hati, lidah, sardin, keju, otak, semua makanan yang diawetkan dengan menggunakan garam dapur; seperti daging asap, ham, ikan kaleng, kornet, dan ebi.

3) Sayuran dan buah yang diawetkan dengan garam dapur; seperti sawi asin, asinan, acar.

4) Garam dapur, soda kue, baking powder, MSG (penyedap rasa).

5) Margarin dan mentega biasa.

6) Bumbu yang mengandung garam dapur yaitu terasi, kecap, saus tomat, petis, tauco.

Pre test yang terakhir yang dilakukan oleh kelompok mengenai penatalaksanaan herbal daun seledri bagi penderita hipertensi didapatkan hasil pengetahuan baik $55,56 \%$.

Setelah dilakukan penyuluhan didapatkan hasil post test dengan pengetahuan baik $86,11 \%$. Hasil penyuluhan bahwa lansia dan keluarga dapat membuat rebusan daun seledri sebagai salah satu pemberian non farmakologi (obat herbal) untuk penurunan hipertensi sebagai berikut:

Seledri adalah tumbuhan serbaguna, terutama sebagai sayuran dan obat-obatan. Sebagai sayuran, daun, tangkai daun, dan umbi sebagai campuran sup. Seledri disebut-sebut sebagai sayuran antihipertensi. Fungsi lainnya adalah sebagai peluruh (diuretika), antireumatik serta pembangkit nafsu makan (karminativa). Banyak sekali manfaat dari seledri, selain dapat menurunkan tekanan darah, seledri juga dapat mengurangi kolesterol tubuh, menyehatkan sendi, mencegah kanker, menyuburkan rambut, mengobati bronchitis, mengatasi alergi dan banyak mengandung vitamin C (Apriliano, 2012).

\section{Alat dan Bahan :}

1) 40 gr seledri

2) Air

3) Gelas

4) Panci

\section{Prosedur Kerja :}

1) Mencuci 40 gr seledri sampai bersih

2) Seledri dipotong-potong kasar

3) Kemudian seledri dimasukkan didalam panci

4) Tambahkan 1 gelas air bersih $200 \mathrm{ml}$ lalu rebus sampai airnya tersisa $3 / 4$ nya

5) Angkat dan tuang kedalam gelas. Rebusan daun seledri siap disajikan/diminum.

\section{Cara Pemakaian :}

Rebusan diminum 2 kali sehari (pagi dan malam)

\section{B. Pembahasan}

Hasil dari pendidikan kesehatan yang dilakukan tanggal 20 November 2019 didapat bahwa pengetahuan peserta rata rata sebelum dilakukan kesehatan $\quad 63,89 \%$ pendidikan kurangpenge- 
tahuan tentang hipertensi dan setelah dilakukan penyuluhan selama 45 menit terhadap 36 peserta didapatkan hasil $80,56 \%$ yang artinya terjadi peningkatan pengetahuan kesehatan sebelum dan sesudah diberi penyuluhan sebesar $16,67 \%$.

Hal ini sejalan penelitian Haryani, Subiyanto, dan Suryani (2018) tentang "Pengaruh Penyuluhan Hipertensi Terhadap Perubahan Perilaku Berisiko Pada Pasien Hipertensi " menunjukkan bahwa ada pengaruh penyuluhan kesehatan terhadap pengetahuan perilaku klien hipertensi.

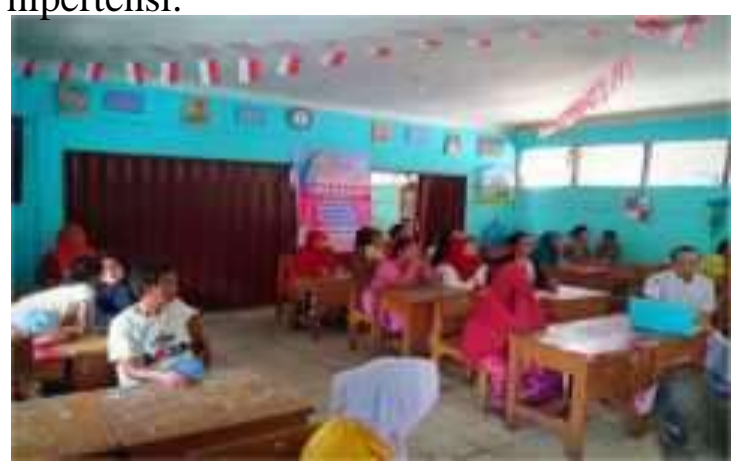

Gambar 1 penyampaian materi

Dari hasil dari penyuluhan $80,56 \%$ peserta mampu menjelaskan kembali pengertian hipertensi, 77,78\% menyebutkan penyebab hipertensi, $75 \%$ menyebutkan tanda dan gejala hipertensi, 77,7\% menjelaskan pencegahan hipertensi, $83,33 \%$ menyebutkan makanan yang diperbolehkan, $\quad 77,78 \%$ menyebutkan makanan yang tidak diperbolehkan, $86,11 \%$ dapat membuat ramuan herbal dengan menggunakan daun seledri sebagai salah satu herbal yang dapat menurunkan tekanan darah.

Hipertensi adalah suatu keadaan ketika seseorang mengalami peningkatan tekanan darah di atas

normal yang mengakibatkan peningkatan angkan kesakitan (morbiditas) dan angka kematian (mortalitas) (Kushariyadi, 2008 dalam Aspiani, 2015). Penyebabnya adalah genetik, obesitas, stress karena lingkungan, hilangnya elastisitas jaringan dan aterosklerosis.

Faktor resiko yang mempengaruhi hipertensi yang dapat atau tidak dapat dikontrol Menurut Elsanti (2009), antara lain: jenis kelamin, umur dan genetik/keturunan. Sedangkan yang dapat dikontrol antara lain :obesitas, kurang olahraga, kebiasaan merokok, mengkonsumsi garam berlebih, minum alkohol, minum kopi dan stress.

Tanda dan gejala hipertensi seperti pusing atau sakit kepala, sering gelisah, wajah merah, tengkuk terasa pegal, mudah marah, telinga berdengung, sukar tidur, sesak napas, rasa berat ditengkuk, mudah lelah, mata berkunang-kunang dan mimisan (keluar darah dari hidung), pencegahan dari hipertensi dapat berupa mengurangi konsumsi garam, menghindari kegemukan (obesitas), membatasi konsumsi lemak, olahraga teratur, makan banyak buah dan sayur segar, latihan relaksasi atau meditasi dan berusaha membina hidup yang postif.

Dalam diet makan hipertensi, makanan yang diperbolehkan berupa bayam, kacang- kacangan, pisang, kedelai, kentang dan coklat pekat. Sedangkan, makanan yang tidak dianjurkan berupa roti (kue yang dimasak dengan garam dapur atau soda); Ginjal, hati, lidah, sardin, keju, otak (semua makanan yang diawetkan dengan menggunakan garam dapur seperti daging asap, ham, ikan kaleng, kornet, dan ebi); sayuran dan buah yang diawetkan dengan garam dapur; seperti sawi asin, asinan, acar; garam dapur, soda kue, baking powder, MSG (penyedap rasa); margarin dan mentega biasa dan bumbu yang mengandung garam dapur yaitu terasi, kecap, saus tomat, petis, tauco.

Penatalaksanaan hipertensi dapat dilakukan dengan 2 cara yaitu secara farmakologis dan non farmakologis. Daun seledri merupakan salah satu terapi non farmakologi yang termasuk dalam pengobatan herbal. Daun selederi sudah diketahui banyak orang memiliki 
kemampuan membantu menurunkan tekanan darah tinggi atau hipertensi. Sudah banyak yang membuktikannya, bisa dimakan dalam campuran jus sayur atau makanan lain, cukup efektif. Manfaat seledri untuk mengurangi tekanan darah sudah dipraktikkan masyarakat sejak lama. Dalam ilmu botani, daun seledri dikatakan memiliki kandungan Apigenin yang dapat mencegah penyempitan pembuluh darah dan Phthalides yang dapat mengendurkan otot-otot arteri atau membuat rileks pembuluh darah. Kandungan itulah yang mengatur aliran darah yang memungkinkan pembuluh darah membesar dan mengurangi tekanan darah (Caraku, 2013).

Menurut penelitian yang dilakukan oleh Sakinah dan Azhari yang berjudul "Pengaruh Rebusan Daun Seledri Terhadap Penurunan Tekanan Darah Pada Pasien Hipertensi Di Wilayah Kerja Puskesmas Pangkajene Kabupaten Sidrap“ (2018) dengan Hasil penelitian menunjukkan adanya Pengaruh Pemberian Rebusan Daun Seledri Terhadap Penuruanan Tekanan Darah Pada Penderita Hipertensi nilai $(p=0,000)$.

Berdasarkan hasil penelitian tersebut dapat disimpulkan bahwa ada pengaruh antara rebusan daun seledri terhadap penurunan tekanan darah pada pasien hipertensi.

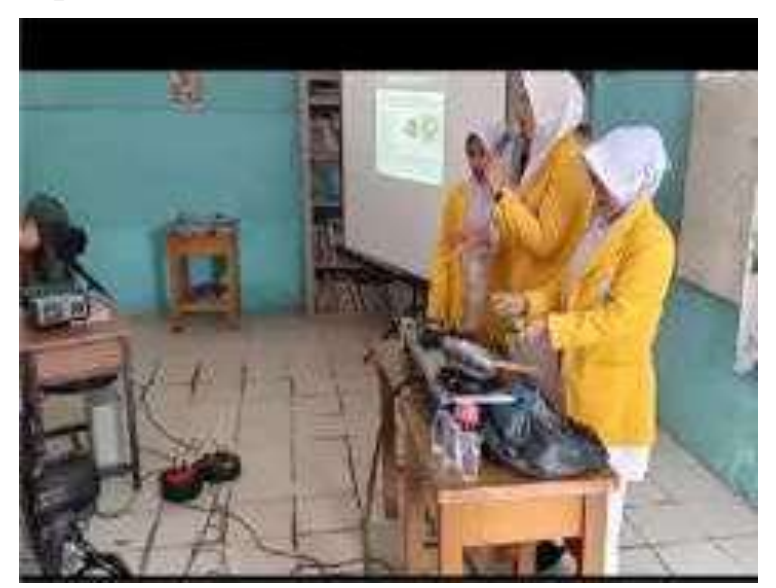

Gambar 2. Demonstrasi pembuatan rebusan daun seledri

Hal ini sejalan dengan penelitian Oktavia, Junaidi dan Ainurafiq (2017) tentang "Pengaruh Pemberian Air Rebusan Daun Seledri (Apium Graveolens) Terhadap Penurunan Tekanan Darah Sistolik Dan Diastolik Penderita Hipertensi Di Wilayah Kerja Puskesmas Puuwatu Kota Kendari Tahun 2016" Hasil uji statistik untuk mengetahui perbedaan tekanan darah sistolik dan diastolik penderita hipertensi kelompok perlakuan dan kelompok kontrol pada hari pertama dan hari kedua setelah pemberian Air rebusan seledri.

Pelaksanaan penyuluhan telah sesuai dengan yang direncanakan yaitu Rabu, 20 November 2019 di SDN 174 Kelurahan Murni, untuk waktu pelaksanaan sesuai dengan rencana pada pukul 14.00 Wib. Sasaran penyuluhan dilakukan kepada lansia beserta keluarga di RT 10 Keluarhan Murni berjumlah 36 orang. Sebelum acara dimulai seluruh peserta pendidikan kesehatan mengisi absensi, mempersilahkan duduk sesuai dengan satuan acara penyuluhan, selanjutnya acara penyuluhan dibuka oleh moderator dan membuka kontrak waktu dengan peserta selama 5 menit. Setelah itu penyaji menggali pengetahuan peserta tentang cuci tangan sebelum penyampaian materi. Penyaji menyampaikan materi selama 10 menit, kemudian mendemonstrasikan pembuatan rebusan daun seledri, 15 menit terakhir dilakukan sesi tanya jawab dan mengevaluasi materi penyuluhan yang telah di sampaikan. Pelaksanaan penyuluhan dilangsungkan sesuai dengan perencanaan kegiatan baik dari pembukaan, penyajian mater, demonstrasi, tanya jawab dan penutup. Dari keseluruhan kegiatan acara penyuluhan hipertensi telah dilaksanakan dengan lancar dan baik, baik dari segi tempat yang kondusif, materi penyaji yang kompeten, demonstrasikan dengan didukung alat dan bahan yang sesuai, serta peserta yang aktif dalam penyuluhan tersebut. 
Setelah dilakukan pendidikan kesehatan tentang hipertensi di RT 10 Kelurahan Murni diharapkan peserta mampu menerapkan hidup sehat dengan mengontrol tekanan darah.

\section{KESIMPULAN DAN SARAN}

Kegiatanpenyuluhan hiper-tensi dan penatalaksanaan herbal daun seledri yang dilakukan pada tanggal 20 November 2019 pada pukul 14.00 WIB di Lapangan SD N 174 Kelurahan Murni dihadiri oleh 36 orang lansia beserta keluarganya di RT. 10 Kelurahan Murni, hasil dari kegiatan penyuluhan adalah lansia dan keluarga mampu menjelaskan kembali materi penyuluhan yang disampaikan dan mengerti serta melakukan penatalaksanaan herbal dengan rebusan daun seledri.

Hasil dari pendidikan kesehatan yang dilakukan tanggal 20 November 2019 didapat bahwa pengetahuan peserta ratarata sebelum dilakukan pendidikan kesehatan $63,89 \%$ kurang pengetahuan tentang hipertensi dan setelah dilakukan penyuluhan selama 45 menit terhadap 36 peserta didapatkan hasil $80,56 \%$ yang artinya terjadi peningkatan pengetahuan kesehatan sebelum dan sesudah diberi penyuluhan sebesar $16,67 \%$.

Setelah dilakukan penyuluhan kesehatan tentang hipertensi dan penatalaksanaan herbal daun seledri di RT. 10 Kelurahan Murni diharapkan lansia dan keluarga dapat mengetahui tentang hipertensi dan melakukan cara rebusan daun seledri. Rencana tindak lanjut dari kegiatan penyuluhan tentang hipertensi adalah Berkoordinasi dengan pihak puskesmas program prnyakit tidak menular (PTM) untuk melakukan penyuluhan tentang hipertensi dengan melibatkan posbindu yang diselenggarakan 1 bulan sekali di 5 kelurahan. Bagi petugas kesehatan diharapkan dapat melanjutkan program yang telah ada dan melaksanakan pengelolaan, supervisi, monitoring serta evaluasi guna kelangsungan kegiatan yang sudah ada.

\section{UCAPAN TERIMAKASIH}

Terimakasih kepada allah SWT karena berkat dan rahmat-Nyalah acara ini bisa berjalan dengan lancar, shalawat serta salam juga tidak kami haturkan pada nabi besar Muhammad SAW, yang telah membawa kita dari zaman kegelapan kezaman terang benderang seperti saat ini, terima kasih kepada Lurah kelurahan murni, ketua RT 10 dan kader RT 10 yang telah mengizinkan kami untuk melaksanakan kegiatan penyuluhan tentang hipertensi, terimaa kasih juga untuk dosen pembimbing atas bimbingan mereka, serta masyarakat RT 10 Kelurahan murni yang telah telah membantu pengabdian masyarakat ini berjalan sukses, kemudian untuk teman-teman kelompok Hippocrates terima kasih untuk kerja samanya, berkat semangat dan batnuan teman-teman acara ini bisa berjalan dengan lancar. Satu kata untuk teman-teman kelompok Hippocrates kalian luar biasa.

\section{DAFTAR PUSTAKA}

Anggraini, dkk. 2009. Faktor-Faktor yang Berhubungan dengan Kejadian Hipertensi Pada Pasien yang berobat di Poliklinik Dewasa Puskesmas Bangkinang Periode Januari 2009.

Arie $\mathrm{Ni}$ Nengah $\mathrm{M}$, Ummu $\mathrm{M} \&$ Trimawart. 2014. Pengaruh Pemberian Air Rebusan Seledri Pada Lansia Penderira Hipertensi Di Dusun Gogodalem Barat. Akademi Keperawatan Ngudi Waluyo Ungaran.

Aspiani,R.L. 2015. Buku ajar asuhan keperawatan gangguan kardiovaskuler aplikasi NIC \& NOC. Jakarta: EGC.

Bustan,M.N. $2015 . \quad$ Manajemen pengendalian penyakit tidak menular. Jakarta: KTD.

Departemen Kesehatan RI. Jakarta 
Depkes RI. 2012. Masalah hipertensi di Indonesia.

Intan Eka Oktavia, Junaidi dan Ainurafiq. 2017. Tentang Pengaruh Pemberian Air Rebusan Daun Seledri (Apium Graveolens) Terhadap Penurunan Tekanan Darah Sistolik Dan Diastolik Penderita Hipertensi Di Wilayah Kerja Puskesmas Puuwatu Kota Kendari Tahun 2016. Fakultas Kesehatan Masyarakat Universitas Halu.

Kemenkes RI. 2018. Hasil utama RISKESDAS 2018. Jakarta: Kemenkes RI.

Kuswardhani T. 2007. Penatalaksaan Hipertensi Pada Lanjut Usia. Jurnal Denpasar: Unud.

Lingga Lani. 2012. Bebas hipertensi tanpa obat. Jakarta Selatan: PT AgroMedia Pustaka

Marliani L, dkk. 2007. 100 Question \& Answers Hipertensi. Jakarta : PT Elex Media.

Peter, Hanns W. 2009. Hipertensi. Diterjemahkan oleh Lily Endang Joeliani. Jakarta : PT Bhuana Ilmu Populer.

Purwati, R.D., Bidjuni, H. \& Babakal, A. 2014. Pengaruh penyuluhan kesehatan terhadap pengetahuan perilaku klien hipertensi di Puskesmas Bahu Manado.

PSIK FK Universitas Sam Ratulangi Manado.

Rohaendi. 2008. Treatment Of High Blood Pressure. Jakarta:Gramedia Pustaka Utama

Rudianto, Budi F. 2013. Menaklukkan Hipertensi dan Diabetes. Yogyakarta: Sakkhasukma.

Sri Sakinah dan Husnul Khatimah Azhari. 2018. Pengaruh Rebusan Daun Seledri Terhadap Penurunan Tekanan Darah Pada Pasien Hipertensi Di Wilayah Kerja Puskesmas Pangkajene Kabupaten Sidrap. STIKES Muhammadiyah Sidrap.
Sutanto. 2009. Awas 7 Penyakit Degeneratif. Yogjakarta : Paradigma Indonesia.

Triyanto Endang. 2014. Pelayanan keperawatan bagi penderita hipertensi secara terpadu. Yogyakarta: Graha Ilmu.

Udjianti,W.J.2010. Keperawatan kardiovaskuler. Jakarta: Salemba Medika. 